\title{
Fatigue Properties of Acrylic Denture Base Resins
}

\author{
Koichi FUJII \\ Department of Dental Materials Science, Kagoshima University Dental School 1208-1 Usuki, Kagoshima \\ 890 , Japan
}

Received on July 31,1989

Accepted on October 12, 1989

Observations were made of fractured surfaces caused by flexural and tensile fatigue tests made in polymethyl methacrylate denture base resins (PMMA). In addition, the changes in dynamic viscoelastic and tensile properties of the materials along with fatigue propagation were investigated.

In the tensile and flexural fatigue tests, both the fractured surfaces, which had striations on their surfaces and cracks near the fractured section, closely resembled each other in appearance. On the other hand, all of the tensile properties, such as elastic modulus, toughness and tensile strength, decreased with the increase of the number of stress cycles in the fatigue test. The storage modulus ( $\left.E^{\prime}\right)$ of the material decreased gradually along with fatigue propagation over the whole range of temperatures tested. The loss modulus ( $\left.E^{\prime \prime}\right)$ and mechanical loss tangent $(\tan \delta)$ increased slightly.

The fatigue limit of four commercial denture base resins varied widely from one product to another.

Key words : Acrylic resin, Fatigue, Dynamic Viscoelastic property

\section{INTRODUCTION}

Polymethyl methacrylate (PMMA) has been widely used in dentistry. Although it has been generally employed as a denture base in order to function more satisfactorily in the mouth $^{1)}$, it is considered that this material is relatively weak in durability, such as under the conditions of repeated flexural stress and strain, and in light resistance ${ }^{2,3}$. Most fractures of the acrylic dentures are caused by repeated stress or strain during mastication. In particular, upper complete dentures often fail during use ${ }^{4}$. Therefore, many studies on flexural fatigue have already been reported ${ }^{5-18}$. However, the mechanisms of fatigue failure have yet to be sufficiently clarified since they are closely related to environmental factors.

The purpose of the present investigation was to elucidate the changes in the dynamic viscoelastic and tensile properties of PMMA along with fatigue propagation.

\section{MATERIALS AND METHODS}

\section{Materials}

1) Experimental resins (pure PMMA)

The materials used in this study, together with the composition, mixing proportions of monomer to polymer and curing conditions are listed in Table 1. The doughs were formed into metal molds for each specimen for the tensile and flexural fatigue tests and were polymerized using a hot press according to the curing conditions shown in Table 1. Thereafter, they were allowed to cool down to room temperature. The specimens employed in the tensile fatigue test were corrected into the size as shown in Fig. 1, then rubbed down 
Table 1 Materials investigated and curing conditions

\begin{tabular}{|c|c|c|c|c|c|c|c|c|c|}
\hline Material & Type & Code & $\frac{\mathrm{L}(\mathrm{ml}}{\text { Monol }}$ & 3) ratio & $\begin{array}{l}\text { Initi- } \\
\text { ator }\end{array}$ & $\begin{array}{l}\text { Cross link- } \\
\text { ing agent }\end{array}$ & $\begin{array}{l}\text { Tempera- } \\
\text { ture }\left({ }^{\circ} \mathrm{C}\right)\end{array}$ & $\begin{array}{l}\text { time } \\
\text { (min) }\end{array}$ & $\begin{array}{l}\text { Pressure } \\
\left(\mathrm{kgf} / \mathrm{cm}^{2}\right)\end{array}$ \\
\hline $\begin{array}{l}\text { Experimen- } \\
\text { tal resin } \\
\text { (pure PMMA) }\end{array}$ & \multirow{2}{*}{$\begin{array}{l}\text { Heat } \\
\text { cured }\end{array}$} & $\begin{array}{l}\text { A } \\
\text { B }\end{array}$ & $\begin{array}{l}8^{* 1} \\
8^{* 1}\end{array}$ & $\begin{array}{l}16^{* 1} \\
16^{* 1}\end{array}$ & $\begin{array}{l}\mathrm{BPO} * 2 \\
\mathrm{BPO}^{* 2}\end{array}$ & $\begin{array}{c}0 \\
\text { EGDMA*3 }\end{array}$ & $\begin{array}{l}70 \rightarrow 100^{* 4} \\
70 \rightarrow 100^{* 4}\end{array}$ & $\begin{array}{l}60 \rightarrow 60 \\
60 \rightarrow 60\end{array}$ & $\begin{array}{l}50 \\
50\end{array}$ \\
\hline \multirow{4}{*}{$\begin{array}{l}\text { Commercial } \\
\text { dental } \\
\text { base resin }\end{array}$} & & C & 8 & 16 & - & - & $70 \rightarrow 100^{* 5}$ & $60 \rightarrow 60$ & - \\
\hline & \multirow{3}{*}{ Pour } & $\mathrm{D}$ & 7 & 10 & - & - & 45 & 15 & 3 \\
\hline & & E & 7 & 10 & - & - & 45 & 15 & 3 \\
\hline & & F & 9 & 15 & - & - & 50 & 20 & 1.5 \\
\hline
\end{tabular}

*1 Monomer and polymer used in this studies are methylmethacrylate (1st class reagent) and polymethy lmethacrylate (Acricon).

*2 Benzoyl peroxide (1st class reagent) concentration used as initiator is $0.5 \mathrm{wt} \%$ to monomer.

*3 Ethyleneglycol dimethacrylate (1st class reagent) concentration used as cross linking agent is $3 \mathrm{wt} \%$ to monomer.

-4 Polymerization was carried out by processing for 1 hour at $70^{\circ} \mathrm{C}$ and then keeping for 1 hour at $100^{\circ} \mathrm{C}$, using the hot press.

*5 Polymerization was carried out by processing for 1 hour at $70^{\circ} \mathrm{C}$ and then boiling for 1 hour in water.

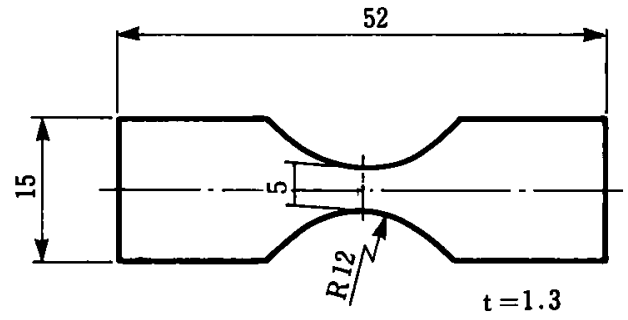

Fig. 1 Specimen shape used for the tensile fatigue test.

with a wet silicone carbide paper (\#600) and polished using $\mathrm{Al}_{2} \mathrm{O}_{3}$ powder $(0.3 \mu \mathrm{m}$ in diameter). Furthermore, the specimens were treated by heating them for 5 hours at a temperature of $110 \pm 5^{\circ} \mathrm{C}$, prior to testing to remove any internal stress and decrease the scattering of the results. Flexural fatigue specimens were also polished using the same method as described for tensile fatigue specimens.

\section{2) Commercial dental resins}

For the heat cured resin, all the specimens were prepared by boiling them according to the dental curing techniques as shown in Table 1 and by using the same mold as for the tensile fatigue specimen. Three commercial pour resins were also employed. Polymerization was carried out in PTFE molds according to the manufacturers' recommendations shown in Table 1. After curing, the external shape of both specimens was corrected and finished to a smooth surface using No. 600 emery paper by hand. All the pour resin specimens were stored in a desiccator for a month at $23 \pm 1^{\circ} \mathrm{C}$ before testing for neglecting the changes of residual monomer within a material.

C: Acron, GC Dental Ind. Co., Tokyo, Japan ; D : Modern Core, Sankin Ind, Co., Osaka, Japan ; E: Palapress, Kulzer, Wehrhelm, Germany ; F : Poly base-S, Nissin Dental Products Inc., Kyoto, Japan 


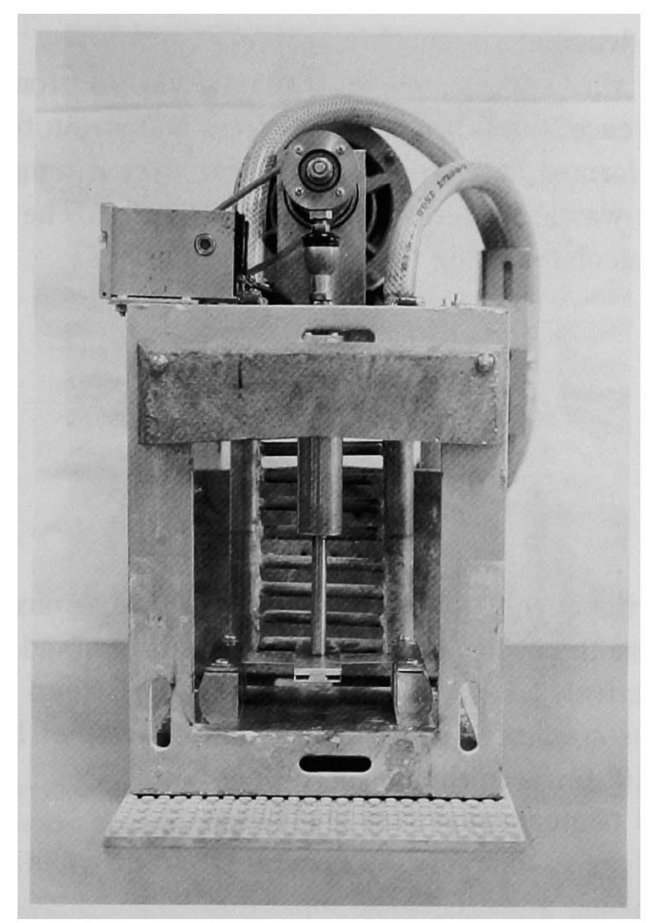

Fig. 2 Apparatus used for the flexural fatigue test.

\section{Methods}

1) Flexural fatigue testing

The apparatus used was an experimental device mainly designed for flexural fatigue tests, as shown in Fig 2. This instrument, which was a cantilever type, was able to give a constant repeated strain to the specimens by means of an eccentric cam attached to the rotating shaft of the motor with a rod joined to it.

Tests were carried out at a span of $35 \mathrm{~mm}$, a deflection of $8 \mathrm{~mm}$ at the free end of the specimen and a repeated flexure of $30 \mathrm{~Hz}$ in air at $23 \pm 1^{\circ} \mathrm{C}$. Only material $\mathrm{A}$, which was not treated by heating, was tested and its specimen size was $40 \pm 0.5 \mathrm{~mm}$ in width and $1 \pm 0.1 \mathrm{~mm}$ in thickness, considering an area of denture base in clinical application.

2) Tensile fatigue testing

The apparatus used was a modification of the fatigue testing machine ${ }^{*}$, to which the repeated constant stress was added by means of unbalanced mass method ${ }^{10-13}$. Tests were performed by applying a repeated stress of $30 \mathrm{~Hz}$ and adding a tensile mean stress to a specimen in air at $23 \pm 1^{\circ} \mathrm{C}$ until each specimen failed, and an S-N curve was plotted.

3) Tensile testing

Tensile tests were performed with a crosshead speed of $0.5 \mathrm{~mm} / \mathrm{min}$ using a universal testing machine ${ }^{* *}$ in air at $23 \pm 1^{\circ} \mathrm{C}$.

: UF-15, Shimadzu Mfg. Co. Kyoto, Japan

$\therefore$ Auto-graph AG-100, Shimadzu Mfg. Co. Kyoto, Japan 
4) Measurement of dynamic viscoelastic properties

The apparatus used was a direct reading dynamic viscoelastometer" ${ }^{*}$, which permitted the angle of phase difference $(\tan \delta)$ between the stress and strain to be measured ${ }^{19-22)}$. All measurements were performed at a frequency of $1 \mathrm{~Hz}$ over a temperature range of 23 to $110^{\circ} \mathrm{C}$. The temperature was increased at a rate of $0.5^{\circ} \mathrm{C} / \mathrm{min}$. The storage modulus $\mathrm{E}^{\prime}$ and loss modulus $\mathrm{E}^{\prime \prime}$ were calculated using the following equations :

$$
\begin{aligned}
& \mathrm{E}^{\prime}=\left|\mathrm{E}^{*}\right| \cos \delta \\
& \mathrm{E}^{\prime \prime}=\left|\mathrm{E}^{*}\right| \sin \delta
\end{aligned}
$$

and

$$
\mathrm{E}^{*}=\frac{1}{8} \times \frac{1}{\mathrm{~A} \times \mathrm{D}-\mathrm{K}} \times \frac{\mathrm{L}}{\mathrm{S}} \times 10^{12}\left(\mathrm{dyn} / \mathrm{cm}^{2}\right)
$$

where $\mathrm{A}$ was the proportional constant of the dynamic viscoelastometer, $\mathrm{D}$ was the dynamic load and $\mathrm{K}, \mathrm{L}$ and $\mathrm{S}$ were the proportional constant, the length and the cross-sectional area of the test pieces, respectively. Rectangular test pieces, $4 \pm 0.1 \mathrm{~mm}$ in width, were prepared by cutting them from the specimens to which a repeated stress of $1.9 \mathrm{kgf} / \mathrm{mm}^{2}$ was applied for $0,10^{5}, 10^{6}$ and $1.5 \times 10^{7}$ times in the tensile fatigue test.

5) Two dimensional photoelastic stress analysis

This analysis was done to examine the general stress distribution in specimens used in the tensile fatigue test, using a photoelastic apparatus ${ }^{23}$.

The material used as test pieces was an epoxy resin with an elastic modulus of $3.07 \times 10^{10}$ $\mathrm{dyn} / \mathrm{cm}^{2}$ at $23^{\circ} \mathrm{C}$. Their shapes were geometrically similar with that of the tensile fatigue specimens and three times the original size, and they were used after polishing with No. 1200 emery paper. The test pieces were heat-treated for 4 hours at a temperature of $90^{\circ} \mathrm{C}$ and then allowed to cool down for 12 hours to room temperature in an electric furnace.

6) Determination of residual monomer

Measurement of the residual monomer was performed using a high performance liquid chromatograph $^{*}$, incorporating two steel columns. After polymerization, the material $(0.1$ g) was weighed and placed into $10 \mathrm{ml}$ of tetrahydrofuran (THF). For pour resin, materials used were stored in a desiccator for a month at $23 \pm 1^{\circ} \mathrm{C}$ after polymerization. A sample of each solution $(10 \mu \mathrm{l})$ was injected into the chromatograph and three measurements were taken at a temperature of $37 \pm 0.1^{\circ} \mathrm{C}$. A standard solution of monomer (MMA) was prepared for the purpose of calibration and the residual monomer (\%) was calculated from the area under the curve at the peak produced by MMA.

7) Microscopic observation

After specimens underwent fatigue failure, their fractured surfaces were investigated using a microscope.

" Rheovibron DDV-III-C, Orientec Co. Tokyo, Japan

$\because$ LC-3A, Shimadzu Mfg. Co., Kyoto, Japan 


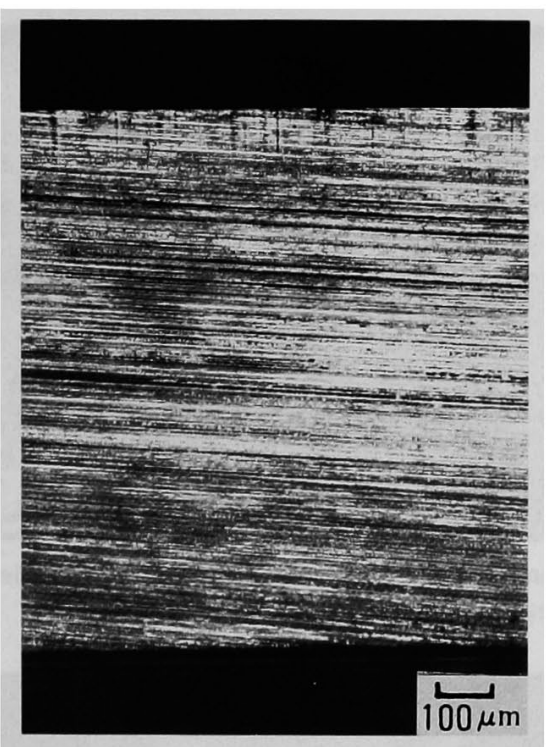

Fig. 3 Cracks developed from the surface of tensile side of the specimen in the flexural fatigue test (in cross-section)

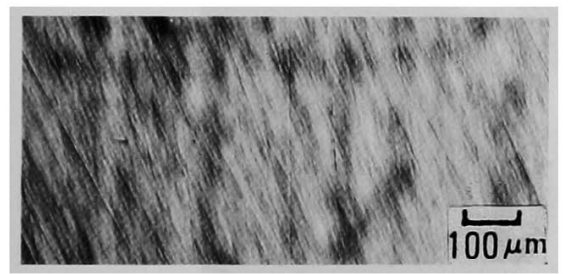

(a)

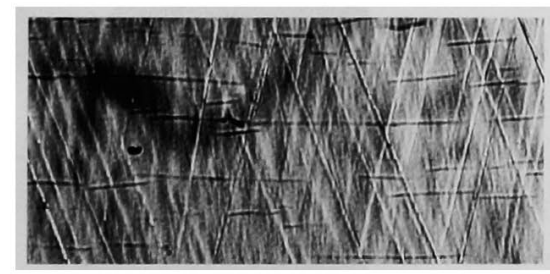

(b)

Fig. 4 Comparison with each surface between the compressive side (a) without cracks and the tensile side (b) with cracks in the flexural fatigue test.

\section{RESULTS}

Figures 3 and 4 show the surfaces of a specimen on which a repeated strain was applied $2.7 \times 10^{7}$ times in the flexural fatigue test on material $\mathrm{A}$ without the heat treatment. The crack was observed on the surface at the tensile side of the specimen. This information will be a useful key in regard to the growth of cracks. Striations were also observed on the fractured surface of a lot of the specimens as shown in Fig. 5, and were detected for the specimen on which the strain was repeated $1.267 \times 10^{7}$ times.

Isochromatics was seen in the epoxy resin specimen as shown in Fig. 6, when a $67 \mathrm{kgf}$ tensile load was added in air at $23 \pm 1^{\circ} \mathrm{C}$. The principal stresses $\left(\sigma_{\mathrm{x}}\right.$ and $\left.\sigma_{\mathrm{y}}\right)$ were calculated using the results measured by means of the construction of the isochromatics and isoclinics, as shown in Fig. 7. From these results, it can be seen that stress concentration within the specimens used in the tensile fatigue test were produced in the middle ( $a$ and $b$ ) of each curved line. 


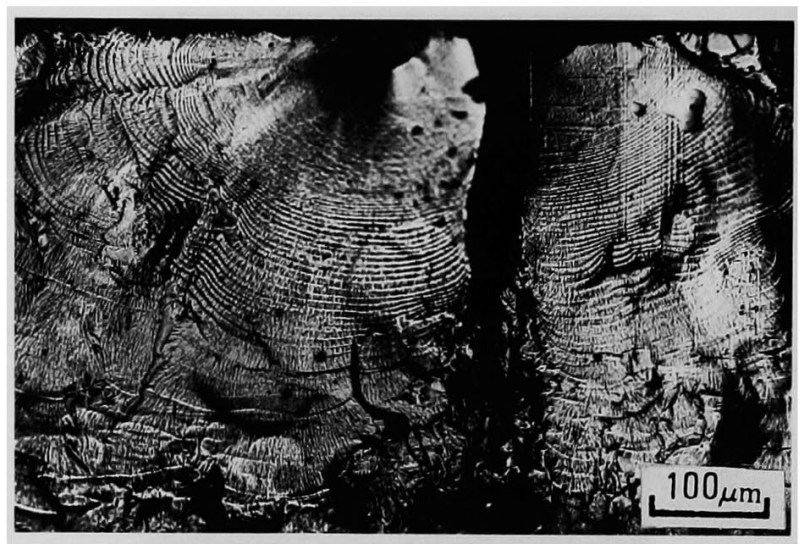

Fig. 5 The striations developed from the surface of tensile side of the specimen used in the flexural fatigue test, on a fractured surface.

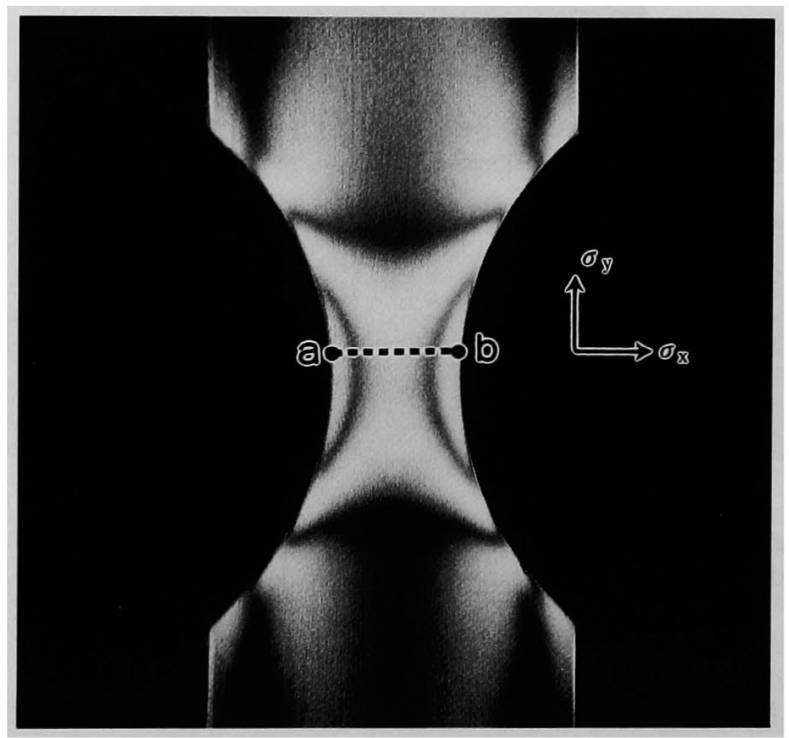

Fig. 6 Isochromatics in an epoxy resin specimen, when $67 \mathrm{kgf}$ tensile load was applied to the specimen in air at $23 \pm 1^{\circ} \mathrm{C}$.

Figure 8 is the S-N curves obtained from each tensile fatigue test of materials A and B. The addition of ethyleneglycol dimethacrylate (EGDMA) to base monomer (MMA) improved the fatigue limit of material A.

Figure 9 shows the S-N curves of material A with a mean stress $\left(\sigma_{\mathrm{m}}\right)$ of $1.5,1.9$ and 2.5 $\mathrm{kgf} / \mathrm{mm}^{2}$. As shown in Fig. 10, the increase of the mean stress brought a decrease in the fatigue limit.

Figure 11 shows the stress-strain curves obtained from the tensile test for each specimen when $1.9 \mathrm{kgf} / \mathrm{mm}^{2}$ of stress was applied repeatedly for $10^{4}, 10^{5}$ and $10^{6}$ times along with 


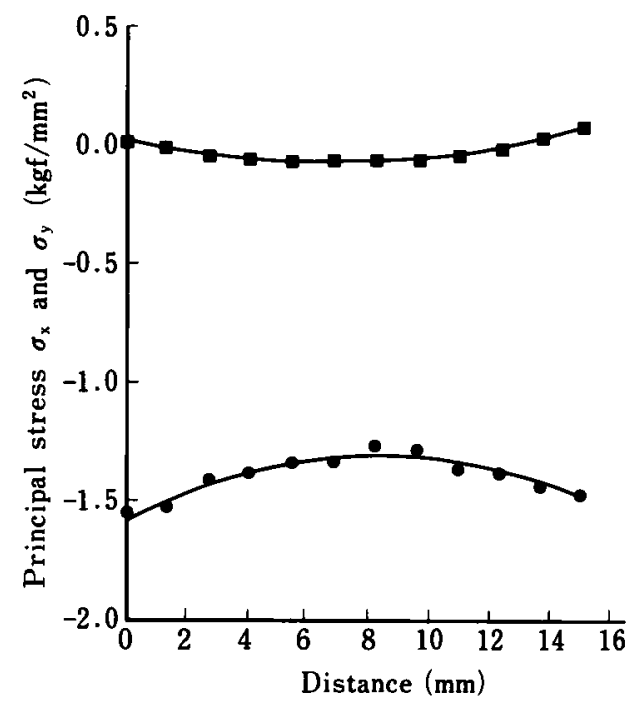

Fig. 7 Distribution of principal stresses $\left(\sigma_{x}\right.$ and $\left.\sigma_{y}\right)$ along line $a-b$ shown in Fig. 6 , obtained by shear difference method: The symbols $\square$ and 0 show $\sigma_{x}$ and $\sigma_{y}$, respectively.

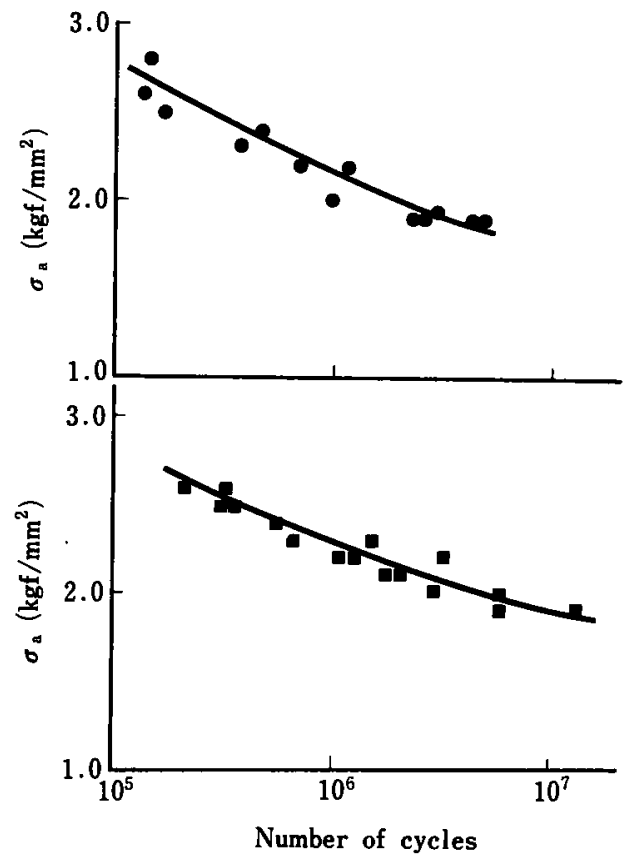

Fig. 8 Variation of stress amplitude $\left(\sigma_{\mathrm{B}}\right)$ with the number of stress cycles in tensile fatigue test in air at $23 \pm 1^{\circ} \mathrm{C}$ : The symbols and show materials $A$ and $B$, respectively. 


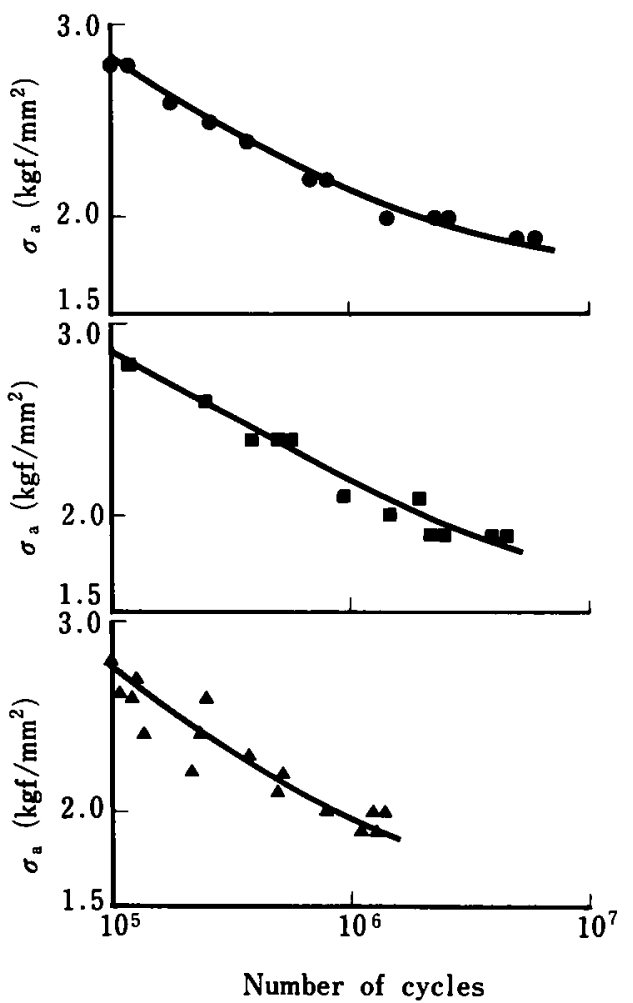

Fig. 9 Variation of stress amplitude $\left(\sigma_{\mathrm{a}}\right)$ with the number of stress cycles for material $A$ in the tensile fatigue test in air at $23 \pm 1^{\circ} \mathrm{C}$ : The symbols $\boldsymbol{\square}$ and $\Delta$ show fatigue behavior at each mean stress of $1.5,1.9$ and $2.5 \mathrm{kgf} / \mathrm{mm}^{2}$.

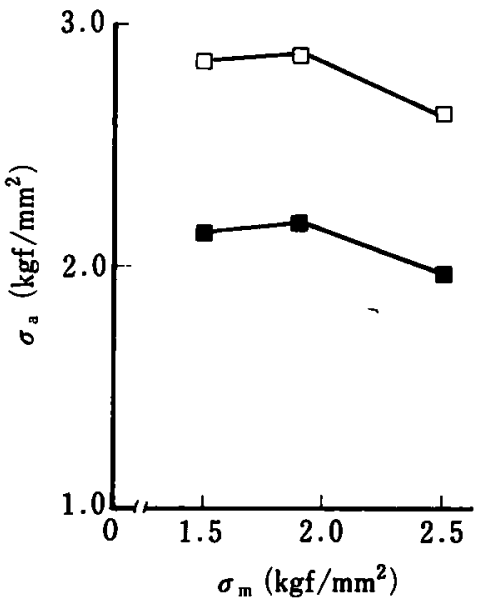

Fig. 10 Relationship between mean stress $\left(\sigma_{m}\right)$ and stress amplitude $\left(\sigma_{\mathrm{a}}\right)$ : The symbols $\square$ and $\square$ are at $10^{5}$ and $10^{6}$ cycles. 


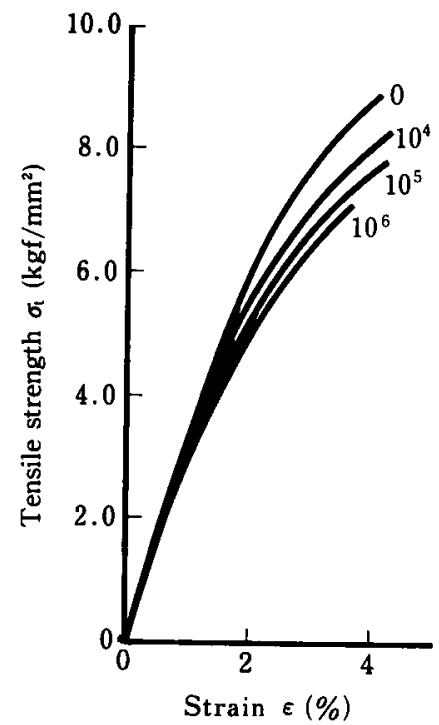

Fig. 11 Stress-strain curves of material $\mathrm{A}$ obtained before and after the tensile fatigue test : The numbers $0,10^{4}, 10^{5}$ and $10^{6}$ indicate the number of stress cycles.

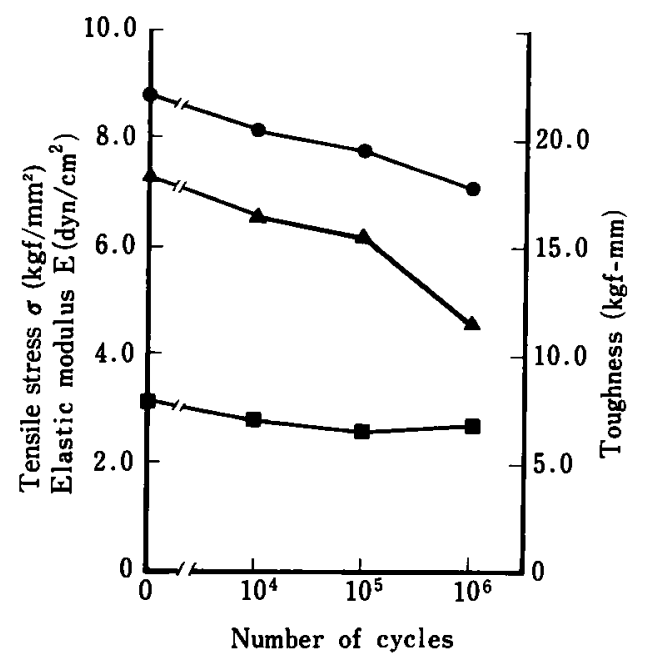

Fig. 12 Variation of tensile properties with the number of stress cycles for material A : The symbols $\square$, and $\Delta$ show the elastic modulus, tensile strength and toughness, respectively.

fatigue propagation. According to the increase in the number of stress cycles, the elastic modulus, toughness and tensile strength decreased, as shown in Fig. 12.

Figure 13 shows the variation in the viscoelastic properties $\left(\mathrm{E}^{\prime} \mathrm{E}^{\prime \prime}\right.$ and $\tan \delta$ ) with the temperature, when measured by using the test pieces cut from the same specimens as described in Fig. 11. With the increase in the number of stress cycles, the storage modulus 


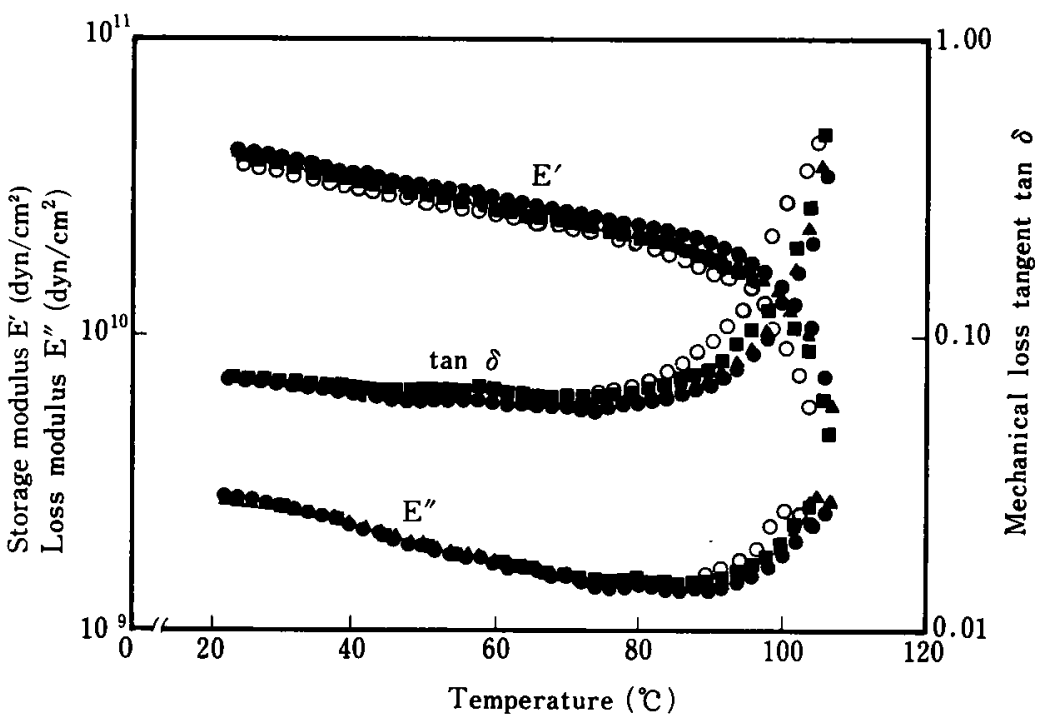

Fig. 13 Variation of dynamic viscoelastic properties with temperature of material A : The symbol $\bigcirc$ shows the specimen before the fatigue test and $\Delta, \square$ and $\bigcirc$ at $10^{5}, 10^{6}$ and $1.5 \times 10^{7}$ cycles, respectively.

$\left(E^{\prime}\right)$ gradually decreased over the whole range of temperatures tested and the loss modulus (E") slightly increased, together with the mechanical loss tangent ( $\tan \delta)$, as shown in Fig 14.

Figure 15 shows the $\mathrm{S} \cdot \mathrm{N}$ curves of material $\mathrm{C}$ measured in air at $23 \pm 1^{\circ} \mathrm{C}$ and in water at $37 \pm 1^{\circ} \mathrm{C}$. The fatigue limit of the specimens soaked in water was smaller than that of the material tested in air.

Figure 16 shows the S-N curves for materials $D, E$ and $F$ in air at $23 \pm 1^{\circ} \mathrm{C}$. The pour resins had low fatigue limits, compared with the heat cured acrylic resin, and their fatigue limits varied widely.

\section{DISCUSSION}

\section{Flexural fatigue test}

A repeated strain of $0.98 \%$, much below the proportional limit, was applied to the specimen. In the case of a repeated strain, it was seen that the stress produced within a specimen decreased with time because of the stress relaxation caused by the flow of the material. Therefore, fatigue resistance may be slightly increased. In regard to appearance of the failure surface, many researchers have already reported a similar tendency ${ }^{4,6,8)}$.

Tensile fatigue test

1) Tensile fatigue behavior of acrylic denture base resin

The endurance limit of high polymers has commonly employed a fatigue strength at $10^{7}$ applications as a tentative criterion for judgment ${ }^{24}$. In clinical applications, it is known that the avarage number of times that a person chews is over five hundred thousand per annum ${ }^{25)}$ 


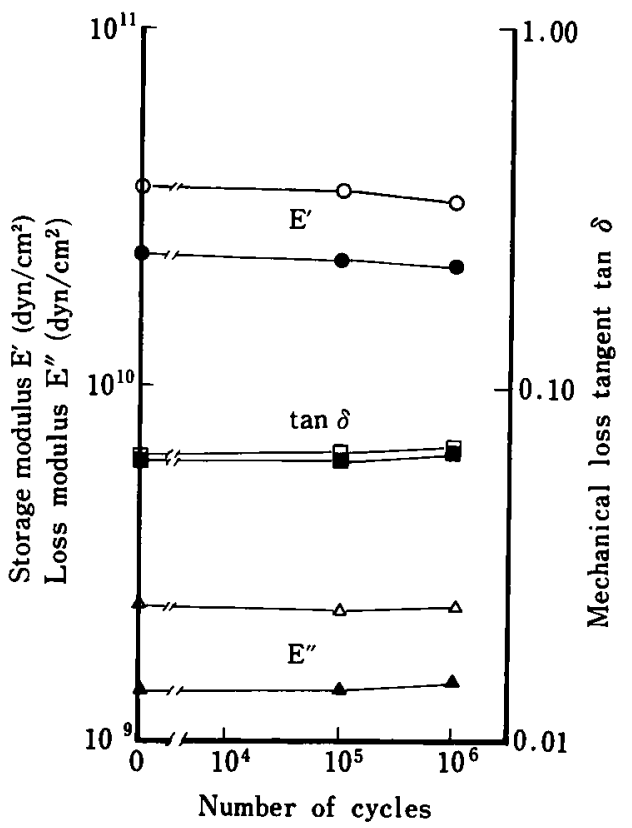

Fig. 14 Variation of dynamic viscoelastic properties with the number of stress cycles: The open and closed notations are at the temperatures of $37^{\circ} \mathrm{C}$ and $80^{\circ} \mathrm{C}$.

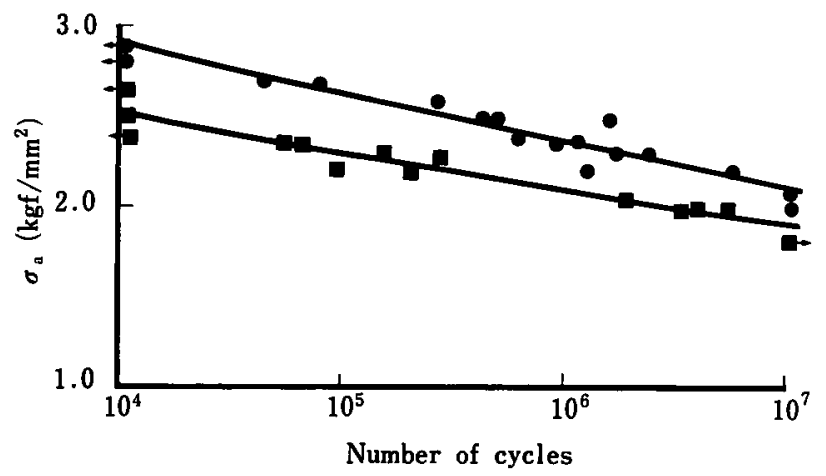

Fig. 15 Variation of stress amplitude $\left(\sigma_{\mathrm{a}}\right)$ with the number of stress cycles for material $\mathrm{C}$ in the tensile fatigue test : The symbols $\mathbf{a}$ are measured respectively in air at $23 \pm 1^{\circ} \mathrm{C}$ and in water at $37 \pm 1^{\circ} \mathrm{C}$.

and that the life span of dentures is about ten years. Therefore, if it is assumed that the fatigue limit of materials is given at $10^{6}$ cycles, it was $2.15 \mathrm{kgf} / \mathrm{mm}^{2}$ for material A and 2.28 $\mathrm{kgf} / \mathrm{mm}^{2}$ for material B. Furthermore, the addition of EGDMA brings an increase in the value of this fatigue limit. This is probably because it produced a crosslinked structure between the molecules. The results in the present study relatively low when compared with the fatigue limits reported by earlier researchers ${ }^{26-28}$. This may be due to the temperature rise generated within a specimen because the testing speed $(30 \mathrm{~Hz})$ was comparatively higher 


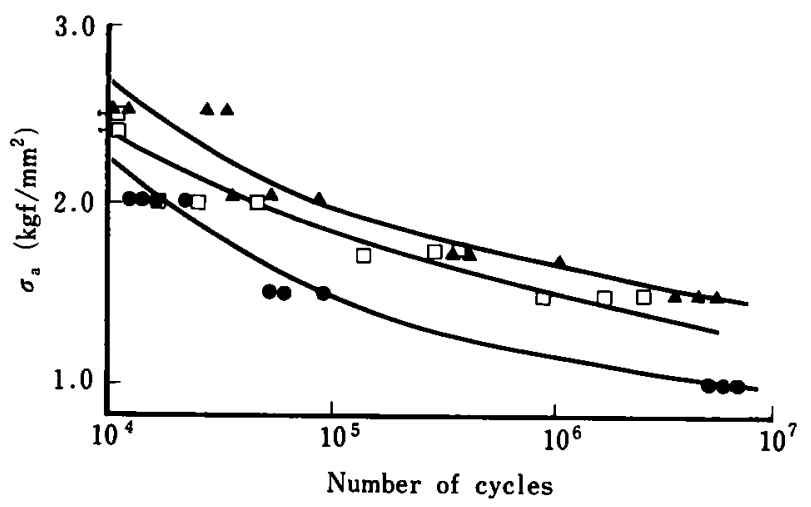

Fig. 16 Variation of stress amplitude $\left(\sigma_{8}\right)$ with the number of stress cycles in the tensile fatigue test in air at $23 \pm 1^{\circ} \mathrm{C}$ : The symbols $\Delta, \bigcirc$ and $\square$ show the materials $\mathrm{D}, \mathrm{E}$ and $\mathrm{F}$, respectively.

than that of earlier investigations. The increase in the mean stress brought the decrease in the fatigure limit as shown in Fig. 10. Also, this result may be closely related with the friction between molecules.

In addition, it was considered that the fatigue failure was induced by the development of cracks in the specimen surfaces and/or a flaw within the specimens, as shown in Figs. 17, 18 and 19. The fractured surface possessed two surfaces, a comparatively smooth surface with striations and a rough surface with many uneven spots. From these results, it can be supposed that the fracture of specimens would occur swiftly when the growth of cracks attained to a certain length along with fatigue propagation.

2) Changes of tensile properties together with fatigue propagation

Specimens in which the number of stress cycles was permitted to increase had a decrease in the tensile properties, such as the elastic modulus, tensile strength and toughness, and it was proved that the decrease of these properties was already commenced at $10^{4}$ stress applications, as shown in Figs. 11 and 12. These results agree well with the results of previous work $^{28}$. But, the elastic limit and Brinell hardness reported in previous work increased a little according to the number of stress cycles. In the case of the appearances of each fractured surface which underwent $10^{4}, 10^{5}$ and $10^{6}$ stress applications, these were similar to the facture surface obtained after the tensile test for the specimen that did not undergo repeated stress. However, there was not striations on the fractured surface, and the fractured surface had a tendency to become a rough surface with a lot of uneven spots when the number of stress cycles was increased. It can be seen that these results are probably made by the development of many cracks along with fatigue propagation.

3) Changes of dynamic viscoelastic properties along with fatigue propagation

It is generally known that the viscoelastic properties of polymers are affected remarkably by their experimental conditions, such as temperature, loading speed and strain $^{29,30}$. One of the purposes of this investigation was to clarify the changes of dynamic viscoelastic properties of denture base materials with fatigue. The frequency used in this study was $1 \mathrm{~Hz}$ in consideration of real chewing ${ }^{31}$. As the number of stress cycles increased, the storage 


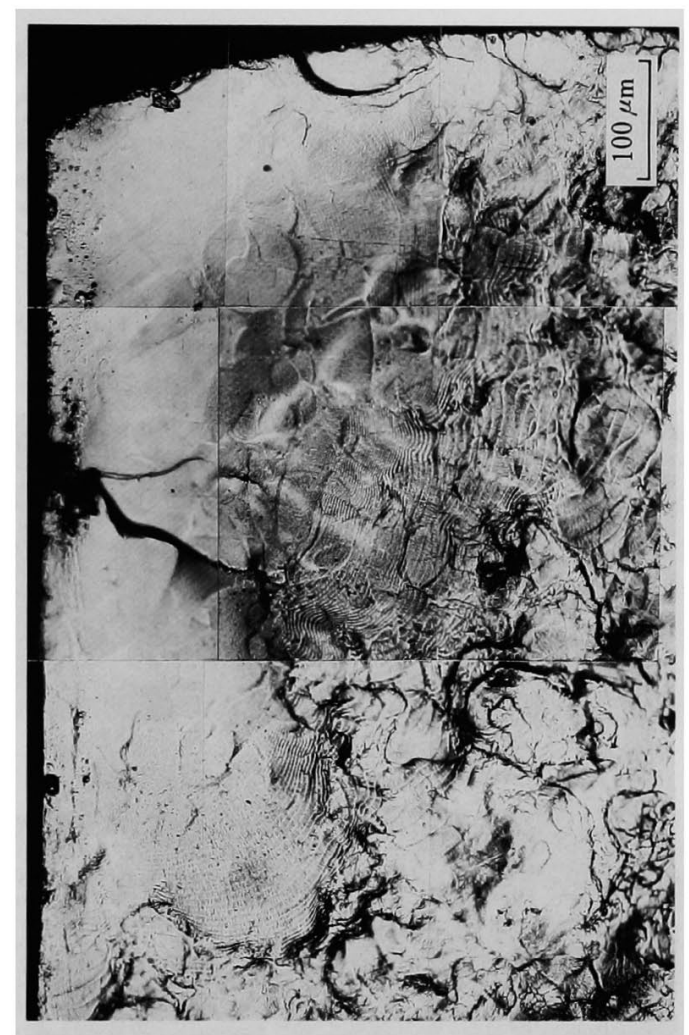

Fig. 17 Magnification of striations on the fractured surface,

modulus $\left(E^{\prime}\right)$ and glass transition temperature $(\mathrm{Tg})$ of the denture base resins decreased gradually over the entire range of the temperatures tested, compared with that of the specimens without fatigue, as shown in Fig. 14. On the other hand, the loss modulus ( $E^{\prime \prime}$ ), which indicates energy lost as frictional heat between molecules, increased slightly with the increase of stress cycles and the same statement was true for the mechanical loss tangent (tan $\delta$ ). It should be noted that these results were also obtained by craking, as shown in Figs. 19 and 20.

4) Fatigue behavior of four acrylic denture base resins

Material C, which was soaked in water, presented the lowest fatigue resistance when compared with materials stored in air. Its reduction rate was about $11.8 \%$. This result indicates that the absorbed water may act as a plasticizer. And this same result was also obtained by an increase in temperature from 23 to $37^{\circ} \mathrm{C}$.

Residual MMA monomer of the material used in this investigation is listed, together with the tensile strength $\left(\sigma_{t}\right)$ and stress amplitude $\left(\sigma_{\mathrm{a}}\right)$ in Table 2. A significant correlation was estimated between them, and the coefficient of correlation was -0.91 for the tensile strength $\left(\sigma_{k}\right)$ and -0.84 for the stress amplitude $\left(\sigma_{\mathrm{z}}\right)$.

From these results, it would appear that the fatigue limit is influenced by the amount of 

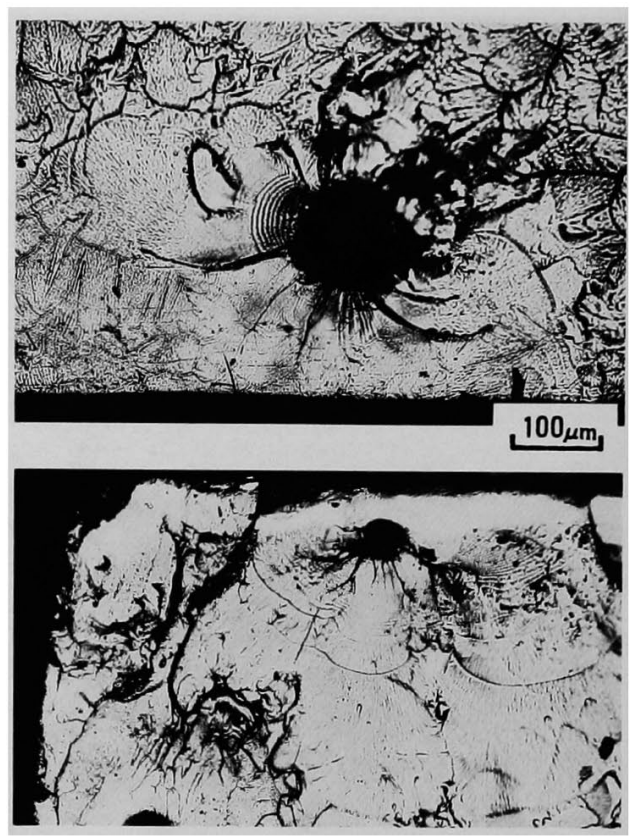

Fig. 18 Magnification of striations developed from a flaw within a specimen.

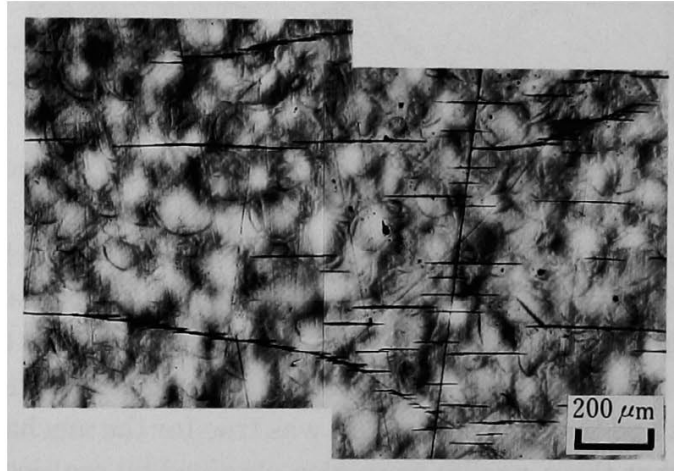

Fig. 19 The development of cracks on the specimen surface near the fractured section.

residual monomer included within each material.

\section{CONCLUSION}

Changes in mechanical and dynamic viscoelastic properties of polymethylmethacrylate denture base resins along with fatigue propagation were investigated using a universal fatigue testing machine, a universal tensile testing machine and a direct reading dynamic viscoelastometer. The summary is as follows :

1) Facture surfaces caused by repeated flexure closely resembled those of tensile fatigue in appearance. 


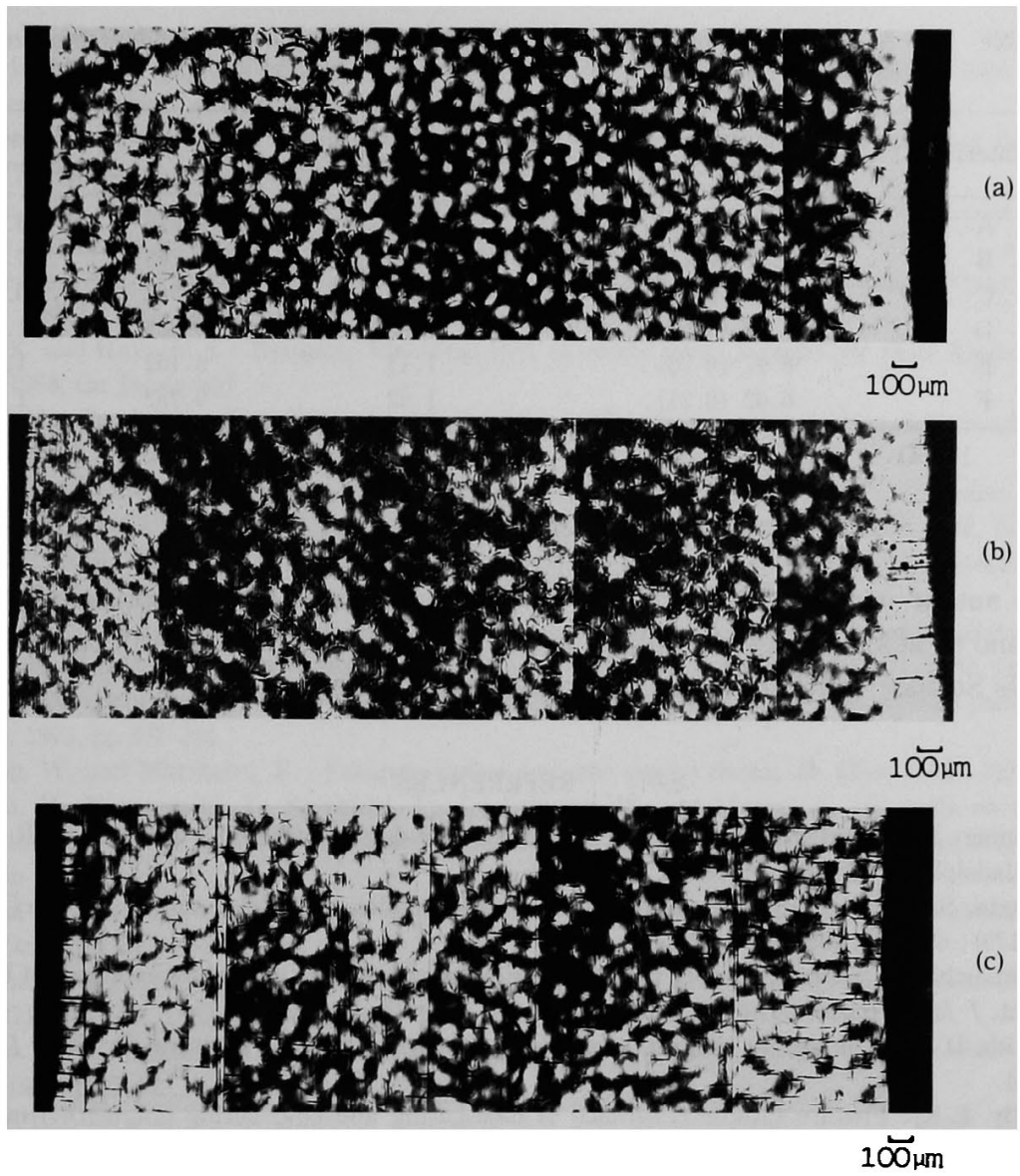

Fig. 20 The development of cracks on the specimen surface together with fatigue propagation: The symbols (a), (b) and (c) are at $10^{4}, 10^{5}$ and $10^{6}$ cycles, respectively.

2) By increasing the mean stress applied to the specimen, the fatigue limit was decreased

3) Along with fatigue propagation, the elastic modulus, toughness and tensile strength were reduced.

4) Along with fatigue propagation, the storage modulus $\left(E^{\prime}\right)$ and glass transition temperature $(\mathrm{Tg})$ were gradually decreased over the whole range of the temperatures tested and also the loss modulus $\left(\mathrm{E}^{\prime \prime}\right)$ and mechanical loss tangent $(\tan \delta)$ increased slightly.

5) The fatigue limit was improved by the addition of a cross-linking agent.

6) Heat cured acrylic resin had a high fatigue limit, compared with that of the pour resins that were tested

7) Water absorbed into heat cured resin caused the fatigue limit to decrease.

8) There was a negative correlation between the amount of residual monomer included within the materials tested and the fatigue limit. 
Table 2 A comparison of tensile strength, stress amplitude and residual monomer for materials used

\begin{tabular}{|c|c|c|c|c|}
\hline Material & $\begin{array}{c}\text { Tensile strength } \\
\sigma_{\mathrm{a}}\left(\mathrm{kgf} / \mathrm{mm}^{2}\right)\end{array}$ & $\begin{array}{l}\text { Stress amplitude } \\
\sigma\left(\mathrm{kgf} / \mathrm{mm}^{2}\right)\left(\text { at } 10^{6}\right)\end{array}$ & $\sigma_{\mathrm{a}} / \sigma_{\mathrm{B}}$ & $\begin{array}{c}\text { Residual } \\
\text { monomer (\%) }\end{array}$ \\
\hline A & $8.74(0.52)$ & 2.15 & 0.240 & 0.41 \\
\hline $\mathrm{B}$ & $8.51(0.18)$ & 2.28 & 0.268 & 0.40 \\
\hline $\mathrm{C}$ & $7.95(0.06)$ & 2.40 & 0.302 & 0.21 \\
\hline $\mathrm{D}$ & $7.09(0.67)$ & 1.62 & 0.228 & 1.75 \\
\hline $\mathrm{E}$ & $6.97(0.73)$ & 1.13 & 0.162 & 1.36 \\
\hline $\mathbf{F}$ & $6.02(0.21)$ & 1.52 & 0.252 & 1.95 \\
\hline
\end{tabular}

\section{ACKNOWLEDGMENT}

The author wishes to thank Prof. Katsuichiro Inoue for his continuing guidance and advice, and to acknowledge the helpful cooperation of the staff of the Department of Dental Materials Science of Kagoshima University Dental School.

\section{REFERENCES}

1) Skinner, E. W. and Phillips, R. W. : The science of dental materials, 6th ed., W. B. Saunders Co., Philadelphia, 1967, pp. 176-189.

2) Okuda, S.: Environmental degradation of plastics under stressed conditions, $J$ Soci Mater Scie J 17(179) : 697-704, 1968. (in Japanese)

3) Yamauchi, H.: Deterioration of Bis - GMA-EDMA copolymers caused by exposure of UV and visible light, J Japan Prosthodont Soc 33(5) : 1130-1144, 1989. (in Japanese)

4) Smith, D. C.: The acrylic denture mechanical evaluation midline fracture, $B r$ Dent $J$ 110: 257-267, 1961.

5) Kelly, E. K. : Flexure fatigue resistance of heat-curing and cold-curing polymethyl methacrylate, $J$ Am Dent Assoc 74: 1273-1276, 1967.

6) Kameda, T., Matsukuma, T., Sakiyama, H., Tennichi, T and Kuroki, M.: Fatigue property of methyl methacrylic resin for denture base, No. 1 on S-N curve, J Japan Soc Dent Appar Mat 9(17): 186-191, 1968. (in Japanese)

7) Kelly, E. K. : Fatigue failure in denture base polymers, $J$ Pros Dent 21(3) : 257-266, 1969.

8) Sakiyama, H., Katsura, H., Ichimaru, T., Tennichi, T. and Kuroki, M. : Fatigue Property of methyl methacrylic resin for denture base, No. $2 \mathrm{~S}-\mathrm{N}$ curve tested in $37^{\circ} \mathrm{C}$ water, $J$ Japan Soc Dent Appar Mat 11(21) : 140-144, 1970. (in Japanese)

9) Stafford, G. D. and Smith, D. C. : Flexural fatigue tests of some denture base polymers, $B r \operatorname{Dent} J 5$ : 442-445, 1970.

10) Miyairi, H., Muramatsu, A. and Saitoh, N.: Influence of surface finishing and polymerization method on the fatigue strength of the dental plastics materials, Repor Insti Medi Dent Eng 5 : 49-56, 1972. (in Japanese)

11) Miyairi, H., Nagai, M. and Muramatsu, A.: Studies on mechanical properties of denture base material laminated with organic fiber reinforced plastics, Part 1 Basic consideration of hybrid construction, Bull Tokyo Med Dent Univ, 22 : 273-280, 1975.

12) Mita, S. : Notch effect on the fatigue strength of the denture base resin, Part 1 Effect of semi-circular notch, J Japan Soc Dent Appar Mat 16(34): 61-66, 1975. (in Japanese)

13) Mita, S.: Notch effect on the fatigue strength of the denture base resin, Part 2 Endurance properties of semi-circular notch, $J$ Japan Soc Dent Appar Mat 16(36) : 211-217, 1975. (in Japanese)

14) Manley, T. R. and Stonebanks, J. A. : A multi-station machine for the fatigue testing of denture base 
materials, Biomater $1:$ 125-128, 1980.

15) Rojczyk, M. and Rojczyk-pflüger, J.: Zur schwellfestigkeit von knochenzementproben bei reiner biegebeanspruchung, Arch Orthop Traumat Surg 97: 39-42, 1980.

16) Johnston, E. P., Nicholls, J. I. and Smith, D. E. : Flexure fatigue of 10 commonly used denture base resins, $J$ Prosthet Dent 46(5): 478-483, 1981.

17) Skirvin, D. R. Vermilyea, S. G. and Brady, R. E. : Polymethylmethacrylate reinforcement : Effect on fatigue failure, Military Medicine 147: 1037-1040, 1982.

18) Hargreaves, A. S. : The effect of cyclic stress on dental polymethylmethacrylate, II Flexural fatigue, $J$ Oral Rehabil 10 : 137-151, 1983.

19) Inoue, K. and Hayashi, I. : Dynamic Viscoelasticity of dental resin, J Japan Soc Dent Appar Mat 9(16) : 11-14, 1968. (in Japanese)

20) Sugino, Y.: Fundamental studies on rheological properties of pour type denture dase acrylic resins, $J$ Kyushu Dent Soc 29(5) : 622-645, 1976.

21) Inoue, K., Arikawa, H., Fujii, K., Kanie, T., Joshin, K., Onizuka, T. and Jimi, T. : Studies on denture base resins, Part 1 Dynamic viscoelastic properties, $J J$ Dent Mater 1(4) : 369-372, 1982. (in Japanese)

22) Inoue, K., Fujii, K., Ikeda, A. and Kakiuchi, T. : Effect of residual monomer on viscoelastic properties of pour denture base resins, Dent Mater $J$ 2(2): 192-197, 1983.

23) Nishizono, N.: Three dimensional photoelastic stress analysis in the abutment teeth and their supporting tissues of semifixed bridge under load, J Japan Prosthodont Soc 32(4) : 887-901, 1988. (in Japanese)

24) The society of polymer science: Handbook for highpolymer materials, lst ed., Corona publishing Co., Tokyo, 1973, pp 307-314.

25) Johnson, W. and Matthews, E. : Fatigue studies on some dental resins, Br Dent J 86 : 252-253, 1949.

26) Kimura, H., Yamaguchi, T., Shiraishi, T., Tsubokawa, M. and Matsui, S.: A study on the fatigue characteristics of the adherends of dental P. M. M. A., J Japan Res Soc Dent Mat Appl 37(1) : 100-108, 1980. (in Japanese)

27) Kimura, H.: A study on the fatigue characteristics of polymethylmethacrylate adherends, $J$ Osaka Univ Dent Sch 20 : 21-30, 1980.

28) Matsumura, Y. : A Basic study on tensile fatigue properties of denture base resins, J Japan Prosthodont Soc 27(2): 374-391, 1983. (in Japanese)

29) Nielsen, L. F. : Mechanical properties of polymers and composites, lst ed., Marcel Dekker Inc., New York, 1975, pp 2-12.

30) Finger, W.: Mechanisch-dynamische eigenschaften von prothesenkunststoffen, Dtsch Zahnaratl Z 30(10): 665-671, 1975.

31) Neil, D. J.: Studies of tooth contact in complete dentures, $B r$ Dent J 123: 369-378, 1967. 
ポリカルボン酸を含む歯科用セメントと歯質との接着機構

電位差滴定からみたカルシウム共存下におけるセメントポリマーの高分子電解質挙動

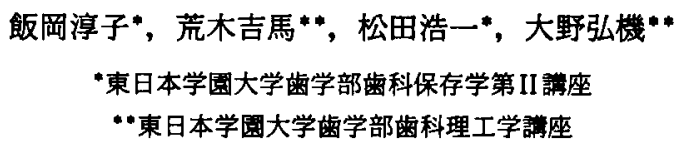

種々な湌度のカルシウムイオンが共存するポリアクリ ル酸およびポリカルポン酸系セメントから分離したポリ マー水溶液の電位差滴定を $\mathrm{NaOH}$ 溶液で行った。その 結果, これら高分子電解質は，カルシウムイオンが共存 しない場合にはいずれも弱酸的挙勘を示した。ところが， ポリマー中のカルボン酸基の䍜度に対して $1 / 2$ 当量以上 カルシウムイオンを共存させると, 各ポリマーは強酸型
の挙動を示した。つまり，このことはアルカリによって カルボン酸を中和してゆくと，解離したカルボキシレー トイオンが共存するカルシウムイオンと強く結合するを 意味している。

したがって,このような挙動は，セメントと霓の間 で起るとされる化学的接着の機軗として有力なものと考 えられる。

義菌床用材料（PMMA）の疲労特性に関する研究

\title{
藤井孝一 \\ 鹿児島大学菌学部歯科理工学讙座
}

義崡床用材料 (PMMA)に咸して，曲げ疲労試験及び 引張疲労試験を行った。さらに引張疲労試験に伴う粘弾 性と引張特性の変化を調へた。

その結果, 疲労試駼後の破面の比较では, 曲げ疲労に よる破面は, 引張側の表面からクラックが開始し，その 後のクラックの進行を表わす striation が現察され，破壊 にいたるという様相を示す。一方, 引張疲労の場合にも 類似の傾向が認められる。

疲労に伴う粘弾性の変化については，疲労が進むと貯 藏弾性率 $\left(E^{\prime}\right)$ は, 湘定されたすべての温度領域で低下
する。一方, 損失弾性率 $\left(\mathrm{E}^{\prime \prime}\right)$, 損失正接 $(\tan \delta)$ はわ ずかづつ増加する傾向を示した。また, 弾性率, 引張強 さ，䩞性などは，10‘回の繰り返し数で，すでに低下を示 していた。これらの結果は, 疲労に伴うクラックの発生 が材料の劣化を招いたものと考えられる。

義歯床用材料として使用されている 4 種類の市販品の 疲労特性を調へた。流し込み型レジンの疲れ強さは加熱 重合型より小さく，材料間で大きことなる。このばら つきの一因として，材料組成の違い，末反応物貝の量の 連いなどが考えられる。

屋外直接暴露試験によるエピテーゼ用シリコーンラバーの変色に関する研究

\author{
鷹股折也*, B. Keith Moore**, Varoujan A. Chalian*** \\ "松本歯科大学崡科補緅学第一㜔座 \\ - Dental Materials, School of Dentistry, Indiana University \\ **Maxillofacial Prosthetics, School of Dentistry, Indiana University
}

エピテーゼ用材料はその使用目的から，顔面皮虍との 色調の調和, 皮问類似性の柔軟性と自然感, 生体親和性 と物理化学的な安定性, 成形か!容易で彩色に優れている ことなどの諸性質が必要とされる。特に, 顔面補緅では, 機械的な劣化以上に，変色が原因で再製作を余儀なくさ
れる場合が多いといわれる。変色の要因あるいは原因は いろいろ考えられるが, これらを検討するには，着色し ていないベースポリマーと着色・彩色の施されているエ ラストマーについてそれぞれ考虑しなければならない。 本研究では，着色・彩色のされていないペースポリマー 